\title{
Chapter 9 \\ Citizenship Education in Post-conflict \\ Contexts: The Case of Algeria
}

\author{
Naouel Abdellatif Mami
}

\begin{abstract}
In most post-conflict contexts, weakened by the large scale of destruction, efforts are often directed towards rebuilding society through preparing citizens to manage conflictual relationships and rebuild at both social and identity levels. This obviously requires the support of citizenship education that models attitudes and civic practices as well as building civic competences.

This chapter focuses on two post-conflict periods in Algerian history. Firstly, we consider the post-colonial period characterized by the need of Algerian society to unite behind a national identity and achieve what the former president Houari Boumedien called "l'Etat - Nation" (the Nation State). From this perspective, we examine the historical complexities around citizenship education in Algeria comprised of three-identity components, namely 'Algerianity', Arabization and Islam. Secondly, we analyze the challenges of citizenship education following Algeria's 'Black Decade' civil war that ended at the start of this millennium. At that time, civic identity was very much influenced by a growing rejection of religious extremism. Finally, we discuss multi-level case studies of educational reforms related to citizenship education as well as changes in the Algerian educational system in terms of participation, conceptions of citizenship, an openness to discuss controversial issues linked to freedom of expression, human rights issues, the participation of women and contextual values of development.
\end{abstract}

Keywords Citizenship · Education - Globalization · Algerian educational system · Post-colonial conflicts

\section{Introduction}

In ancient Greek society, citizenship referred to a person's status as a member of a city. Access to citizenship status granted privileges that other inhabitants such as slaves were denied. In its modern sense, the concept of citizenship has evolved to recognise legal members of a sovereign state who assume duties and enjoy rights.

N. Abdellatif Mami $(\square)$

Mohamed Lamine Debaghine, Sétif 2 University, Setif, Algeria

(C) The Author(s) 2020 
Therefore, the concept of citizenship is linked to the nature of the state and its jurisdiction.

Wider definitions of citizenship are based on a democratic legal rational and include both social and human components that ensure equality without distinction of gender, race or religion.

According to Sarr (2010), citizenship confers equal civil, political, social and economic rights for all. It also defines obligations within the framework of a given political community and allows power sharing and participation in decision-making. Citizenship is therefore expressed through civic behavior involving a set of moral qualities and civic duties considered necessary to smoothly govern the city, where each citizen accepts the common rule of law. Defined as such, citizenship is an essential component in the creation of society (Bendif 2016), generating the need for citizenship education.

Today, citizenship education pays a key role in schools with the aim of both building and training citizens. Indeed, through socialization and education children acquire the knowledge, skills and values necessary to develop and evolve in their community, affirm themselves as free individuals, act responsibly and respect the legal framework that defines individual rights and duties.

However, this initial socialization period should not simply result in strict compliance with the established social norms and models (Rocher 1970). Children's characters are fostered by active debate between various components of their social environment. At times, active citizenship may lead to opposing or even rebelling against what can be considered inappropriate, unjust or unacceptable.

The difficult behavior that some young people may display during adolescence can be linked to a feeling of social exclusion or a citizenship crisis but can also be a phase of intense self-realization and affirmation. This can explain some of the difficulties that occur between the school system and young people. The resulting tensions are partly explained by the inadequate responses of the schooling system to the learners' inherent physical, psychological and social needs. For this reason, it is not only necessary to uphold the educational system but to adapt citizenship education to critical periods of development.

Citizenship education also plays an important role in regulating behavior during traumatic and post-traumatic situations. In this context, it is essential to train teachers to incorporate the principles of democratic citizenship education in their practice.

In recent years, citizenship education has been the subject of international attention, including two major cross-national studies (Jaramillo and José 2009). However, few reviews of citizenship education include research from post-conflict societies (Robertson 2011), a regrettable omission since post-conflict situations offer distinct challenges in terms of instilling both democratic norms and a sense of social cohesion.

This chapter will focus on two post-conflict periods in Algerian history by first considering the post-conflict period following decolonization and analyzing the historical complexities around citizenship education in Algeria during this time and the need for society to unite behind a national identity comprised of three components, namely 'Algerianity', Arabization and Islam. Then, we will examine the challenges 
for citizenship education following Algeria's 'Black Decade' civil war and the fight against religious extremism. Finally, we discuss citizenship education in national educational reforms and issues related to freedom of expression, human rights and women's participation.

\section{Definition of Citizenship Education}

Citizenship education plays a significant role in the development of informed and responsible citizens aware of their duties and rights. To this end, school curricula often includes civic education, religious education or citizenship education. Despite the disparity of these subjects, the implicit or explicit objectives sought through civic, moral or religious education are similar as they all inculcate social behaviors associated with respect of social and legal norms.

It is however important to underline that citizenship education is not exclusively a matter of school curricula, it is also constructed or deconstructed under the influence of educational and pedagogical values that are linked to the economic, political, social, cultural, and institutional practices. It is influenced by context and by social, political and human paradigms.

UNESCO (1998) defines citizenship education as educating children, from early childhood, to become clear-thinking and enlightened citizens who participate in decisions concerning society.

In a democracy, citizenship education seeks to educate citizens who will be free to make their own judgements and hold their own convictions. Compliance with existing laws should not prevent citizens from seeking and planning better and ever more just laws. Respect for law, which is one of the objectives of civic education, calls not for blind submission to rules and laws already passed but the ability to participate in drawing them up (UNESCO 1998, p. 1).

UNESCO (2010) defines citizenship education as the development of skills including "a willingness to investigate issues in the local, school and wider community; a readiness to recognize social, economic, ecological and political dimensions of issues needed to resolve them; and the ability to analyse issues and to participate in action aimed at achieving a sustainable future" (UNESCO 2010, para. 1).

\section{Citizenship Education in Algeria}

To understand citizenship education in Algeria, it is essential to mention a set of components that come into play. Firstly, the concept of citizenship has different connotations and is highly context-dependant. It can therefore have a vast and varied scope depending on territorial context (the Algerian territory defined by national borders) or national context and identify components such as 'Algerianity', 
Arabization, Tamazight (Berber), and Islam. If we consider Algerian citizenship as a sense of belonging to Algeria and consider the country's historical, economic, sociological and political environment, we can distinguish three levels of identity in the Algerian society:

1. The territorial level: identified as belonging to a state in its territorial and legal sense (Algeria).

2. The official linguistic and cultural levels: exemplified by the common use of Arabic and the introduction of Tamazight as a second official language in 2016.

3. The religious level: belonging to the same religion, Islam, in which the relationship between the faithful and the nation (the Ummah) is dictated by Islamic law.

It is important to understand that these three levels of identity are not sufficiently integrated or harmonized at the national level, which is why we have chosen not to adopt the concept of "Nation" in this chapter. Indeed, it could be said that these levels function independently, each with their own logic and political, economic, diplomatic and strategic management, sometimes clashing violently, creating armed conflicts as was the case during the 'Black Decade' civil war. In this respect, these three levels of identity, imposed or rejected, constitute a problem of integration and harmonization.

Secondly, considering the different dimensions of citizenship education, a larger problem emerges linked to the lack of a shared conceptualization of Algerian citizenship. This hampers the promotion and development of citizenship education. In fact, educating the learner to democratic citizenship hardly creates consensus.

Thirdly, it seems hard to link the pedagogical objectives of citizenship education and global citizenship education (GCE) with the current educational discourse in Algeria. Moreover, the gap between discourse and reality hampers the implementation of educational reform projects such as the PARE reform which was initiated in 2002 and a second reform in 2014 in favour of citizenship education. In order to address these intricate issues, it is important to understand Algeria's historical background and analyze the country's current post-conflict situation.

\section{Citizenship in Algeria: A Historical Debate}

Citizenship is a fundamental issue in postcolonial educational systems. Since the country's independence, there has been little opportunity for people to express themselves freely and few possibilities for plural expression. In fact, citizenship education has only very recently become a popular subject. Following the decolonisation process in Algeria, political measures were mainly aimed at building resilience after 132 years of colonization and the war of independence that lasted more than 7 years. Less consideration was given to the social and civil needs of the people and, as a result, the educational sector was not a priority.

Algerians suffered from the French colonization which dispossessed them of their lands and wealth, but also prevented access to education by closing all the country's Koranic schools (Medersa). The horror of colonialism remains in Algeria's 
collective memory, in particular the massacre 8 May 1945 that Zoubir (2011) describes as "the fierce campaign that was conducted on behalf of the French state [that] has made tens of thousands of victims. The number has never been accurately determined, although our national memory recorded symbolically 45000 martyrs" (p. 2). This was followed by many other tragic events such as the massacre that took place on 11 December 1960 and the murders committed by the Secret Armed Organization (OAS) between 1960 and 1962.

Moreover, colonialism has left Algerian society deeply scared. The French colonialism not only affected Algerian society in general but also the people's dignity, religion, identity and citizenship. One example of the French denial of Algerian citizenship is the "code de l'indigénat" which placed Algerians on the same level as slaves. The colonial conquest was also responsible for the impoverishment of Algeria. As stated by Zoubir (2011), "The famine and impoverishment that followed the colonial conquest, [resulted] in the loss of one third of the native population between 1830 and 1870" (p. 2).

We believe the identity issues that the Algerian people experience today are directly linked to the French government's refusal to recognize the crimes committed during colonization. This lack of recognition is regarded as an open wound and as continued denial of Algerian national identity and citizenship. For instance, up until 1999 the French government referred to the Algerian war as simply policing. It is fair to say that Algerians do not adhere to France's appalling claim that colonization was a civilizing mission and a means to prosperity for the Algerian population.

During the colonization of Algeria, the French colonial power massively invested in the country's integration into the French economy, which influenced the territorial organization and in turn upset local social, economic, cultural, and military organization (Abedellatif 2014). This resulted in an unequal geographical distribution of the population with $60 \%$ of the current population concentrated in only $4 \%$ of the territory, leaving the Highlands and the South sparsely populated (Bendif 2016). This massive urbanization represents an important social and educational challenge.

It is undeniable that French colonization damaged the Algerian spirit at all levels (Abdellatif 2014) and had a considerable impact on citizenship and citizenship education. In this respect, Algeria directed its efforts towards creating a sense of national belonging following the decolonization. To do so, it was necessary to promote a shared vision of the 'Umma' Algerian Nation. At that time, the President Houari Boumediene's policy aimed to create a balanced identity as well as fair and functional administrative, economic, industrial, social and cultural organizations. The cultural homogeneity and the multidimensional political equilibrium created in 1971 was the most credible factor of consciousness and national unity.

Since the county's independence, leaders have created a discourse that depicts the national territory in a quasi-sacred way. Despite the political will to fairly create basic infrastructure, provide services, as well as distribute employment and resources, the means to achieving this were not sufficiently thought out and 
unfortunately generated disparities and regional imbalances that have led to divisions in national unity at the level of citizen consciousness.

An important element that must be taken into consideration in Algeria is Islam. Algeria has a rich and diverse cultural heritage stretching from the regions of the great South, the southern and northern slopes of the Atlas to the Mediterranean coastal strip and the High Planes. The environmental diversity and specific historical context have created cultural diversity. Despite this, Islam as the common denominator has shaped the context of everyday life and united the national conscience of Algerian citizens.

The first government after independence restored Islam and the Arabic language. Articles 4 and 5 of the 1963 Constitution stipulate that Islam is the religion of the state and that the Arabic language is the national and official language. This was a legitimate and expected reaction after the oppressive practices of French colonialism but this political act denied the existence of the Tamazight-speaking Berber who constitute a third of Algeria's population (Abdellatif 2016). Thus, postcolonial Algeria has imposed an Arab-Islamic ideology, opposing all forms of cultural and linguistic diversity. The legislative proposals of Colonel Houari Boumediene (President of Algeria from 1965 to 1978) focused on the goal of creating an "authentic Algeria" (Déjeux 2008, p. 5) based on a unified national culture that aimed to reinforce the Arab-Muslim national identity.

In this context of "linguistic purification" (Abdellatif 2014, p. 45), an educational approach based on 'Algerianity', Arabization and Islamic citizenship was adopted. An ideology of monolingualism began to take hold and many feared the loss of the country's diverse linguistic heritage. The post-colonial government introduced an Arabization policy into primary schools through citizenship education and tensions among the population began to spill over into the political scene and violent clashes between students erupted.

The design of the national citizenship education curriculum reflected the values of the 'Nation' and a certain ideological, socialist and cultural approach which excludes Tamazight language and Berber culture. Under the presidency of Colonel Chadli Benjedid, the Algerian Parliament adopted on 19 August 1986 a law 86-10 creating the Algerian Academy of the Arabic Language (Grandguillaume 1997). This forced Arabization was later recognized as a serious political mistake.

In 1995, steps were taken towards the recognition of Tamazight with the introduction of a number of schools and universities in the Berber region. Nevertheless, the socio-political situation was not favourable to finding a definitive solution to the Berber issue and has remained an unresolved source of conflict regarding citizenship and citizenship education.

In June 1990, the Islamic Salvation Front (FIS) won its first democratic municipal elections and a state of emergency was declared. At the same time, President Chadli was able to pass the Arabization Act on 16 January 1991 but it was postponed several times before he was deposed by the army on 11 January 1992. After the High Security Council (HCS) cancelled the results of the elections and appointed Mohamed Boudiaf head of state, Algeria faced a destructive spiral that became known as the 'Black Decade'. During his short mandate, Mohamed Boudiaf 
announced that the Algerian population should speak 'Algerian Arabic' (Derdja) and combat radical Islamism, and the efforts made towards recognizing cultural diversity and fostering citizenship were weakened.

President Abdelaziz Bouteflika acceeded to power in April 1999 and started a policy of national reconciliation and openness to the Western world. On a linguistic level, President Bouteflika often spoke French and demonstrated a certain amount of cultural freedom. Finally, in April 2002, the Algerian parliament changed the constitution to recognize Tamazight as a national language. Since then, Tamazight is taught in primary schools and high schools and a Tamazight bachelor degree has been created in the Universities of Bejaia and Tizi Ouzou. A further revision of the constitution in 2016 gave the status of "national and official" language to Tamazight which was introduced into all schools in Algeria (Constitution of Algeria 2016).

Overall, from a sociological perspective, we can see that since Algeria's independence, Colonel Boumediene's plan to build an educational system based on a 'pure Algerian identity' or an 'authentic Algeria' has never been fully accomplished. The reason being that the break with colonial schooling has had incalculable repercussions on individuals, society and the Algerian educational system as a whole. The relation between national politics and citizenship were defined in the 1963 constitution. From then on, the educational debates revolved around the development of curricula in line with the new principles of an independent Algeria. However, like other colonized countries, the Algerian educational system was a copy of the French system adopting a neo-colonial approach.

We can see that the intricacies of Algerian history and the country's cultural and linguistic diversity has complexified the search for national identity and weakened the basis of citizenship education.

\section{Citizenship in the National Educational Debates}

Fully formed citizens succeed in making their own demands heard but know how to listen to others, to be prepared to compromise while refusing to be compromised, to confront certainties and rigid or dogmatic mindsets, even those in their own cultural and religious community. This is not easy to achieve and requires time, patience, empathy and determination.

After more that 2,00,000 people died in the 'Black Decade' civil war that ended in 2002 the generation which had not witnessed colonialism nor experienced the glories of independence had to face a form of black out in relation to their identity and historical truth. They felt that their history had been betrayed and that they needed to find peace, not only with the past, but also with the present.

In the aftermath of the 'Black Decade', citizenship education was introduced in schools at all levels of instruction aiming to create a coherent framework within a 
'triple harmonization strategy', linking knowledge, pedagogical practices, didactic approaches and concrete practices. Unfortunately, despite these efforts, the design was inadequate to meet the needs of a modern and open society. Abdellatif's (2014) analysis of middle school citizenship education textbooks revealed that they have not benefited from the 'triple harmonization effort', rather they have adopted formalistic approaches to citizenship that carry the risk of favouring perverse forms of citizenship to the detriment of autonomous and responsible citizenship.

Not only do citizenship education programs in Algeria have to combine different levels of citizenship, they are exposed to what Selye (1956) described as sources of stress. One is situated in the environment and the social context in which the learner operates and the second is found in the post-trauma of civil war.

It is also true that since the country's independence, development efforts have not been sufficiently integrated, implemented or evaluated. Consequently, the country has experienced rapid social changes that have been insufficiently controlled. Population pressure in terms of birth rates and geographical mobility have provoked regional and social imbalance, posing, among other things, a challenge for spatial planning.

Furthermore, post-independent Algeria faces new social and economic challenges resulting from globalization. Traditional values of patriarchy and agrarian production clash with the demands of economic, social and political modernization. This has resulted in a multifaceted growth crisis, which destabilizes economic and social development.

In view of these rapid changes, citizenship education programs have registered a number of shortcomings in their compliance with the new socio-economic needs of the country and policies strive to respond to the socio-economic openness of the international market and promote both a change in mentality and in ideological practices while preserving Algerian identity.

In the midst of the 'Black Decade' civil war, a reform was launched in 1998 to improve the educational system and save national education from drifting. A multidisciplinary team aimed to support the development of educational content and develop tools to keep students in school, away from ideological influence. The mission was consistent with the introduction of other educational reforms and the overhaul of educational programs.

A few years later, the trauma causes by the civil war and the socio-economic repercussions engendered by globalization required a new comprehensive educational reform to prepare students for a new sense of citizenship. The national reform launched in 2003 had to face the challenge of unifying educational debates in order to overcome what Avanzini (1998) described as "the crisis of representations and social models" and necessitated serious reflection on the objectives to be achieved in terms of equal opportunities. According to Toualbi-Thaâlibi (2005), the 2003 educational reform was the result of a critical reflection that aimed to reconcile various questions about the new goals of education.

The introduction of a 'smart school' focused not on teaching citizenship education as a national concept but on teaching about citizenship as an international 
vehicle for intercultural dialogue. With this objective in mind, the new textbooks published in 2014 introduced the concept of GCE for the first time.

With the recent reforms, there has been a concerted effort to promote cultural and religious diversity in new textbooks. The decentralization of Arabization was the starting point of this reform, which is part of a larger initative: "as countries in the Arab world embark on the long road toward political transition and attempt to build more open and pluralistic political systems, the need to prepare citizens to become contributors to democratic societies has become increasingly urgent" (Faour 2013, p. 3).

Today, Algeria's educational system is clearly oriented towards the promotion of a new identity for students based on global citizenship. New educational programs have been introduced focusing on human rights issues and the role of women in the establishment of a prosperous society.

\section{The Struggle of Women in Algeria and Citizenship Education}

The current crisis of citizenship, calls for urgent measures to reshape schooling in general, and citizenship education in particular. Nevertheless, the challenge is to conceive of a more realistic, active and methodologically sound approach to citizenship education.

Indeed, according to Perrenoud (1997), the Nation State, which historically exercised more control over its citizens, is no longer the only means of establishing civil society. A greater ability to objectify information, knowledge and values, made possible by human and technological progress in all fields, has fostered more critical and independent thinking. New worldwide approaches in favour of Human Rights have proposed indicators for citizenship education based on respect and sustainability.

Algeria, along with Tunisia, ranks top of Arab countries in recognizing women's rights in their constitutions. Female activists have long challenged marginalization in conservative male-dominated environments and Algerian women's struggles go back to the revolutionary war of 1954-1962. Progressive statements promoting gender equality in a free Algeria have faced opposition from nationalists not well accustomed to female activism.

Salhi (2003) explains that "the challenge of Algerian women during the liberation struggle was on two fronts: it was, simultaneously, a rebellion against the colonial occupation of Algeria by France, and against the restrictive attitudes of traditional Algerian society" (p. 27). In fact, gender discrimination was widespread until the middle of the twentieth century and was inspired by patriarchal values common to monotheistic religions. When the first legislation on citizenship was adopted in 1963, women had not yet gained equality in terms of citizenship rights, not only in Algeria but also in many other parts of the world. 
The latest reforms of citizenship laws in Algeria, mainly the 2016 constitution, have improved women's rights in the country. Algeria is the only country in the Arab world to give women the right to pass on their nationality to a foreign husband.

Gender equality in the Algerian educational system and citizenship education in the second-generation textbooks in Algeria enables Algerian pupils to use the powerful tools of education and civic participation in order to empower women to become leaders in their own right.

One important measure taken in favor of women's empowerment in Algeria is the development of networks to drive the advancement of women and increase their participation and visibility in key sectors of society. Based on the belief that development hinges on the sustained participation of women in socio-economic spheres at all levels and across all sectors, citizenship education includes the construction of networks, underpinned by a philosophy of citizen engagement at the national level.

Overall, progress on individual rights in Algeria has mainly resulted from the collective struggle of women. The reforms adopted in education have allowed women to feel more legitimate and determined to make changes in society in order to advance citizen equality and global citizenship.

Social science has identified a link between women's empowerment and improvements in society. Gender equity programs must therefore include GCE and help women participate in global initiatives and fight against violence, child abuse and discrimination. Indeed, countries with strong women are generally better advocates against all forms of human rights abuse as explained by Brysk (2009).

\section{Conclusion}

Since independence, Algeria has expressed an interest in the ways in which its youth are prepared for citizenship and how they learn to take part in the 'Nation's' civic life. Today, that interest might better be described as a growing concern, particularly related to young people's search to build a democratic society. Perhaps no country has yet achieved the level of understanding and acceptance of the rights and responsibilities of all its citizens required for the maintenance and improvement of a constitutional democracy.

The performance of the Algerian school system is therefore not reducible to its sole capacity to inculcate knowledge but measured by its ability to empower pupils and students. It should also consider the education and training of knowledge and attitudes, compatible with all the constituents of an Algerian identity and supported by a non-exclusive and coherent historiography, far removed from strategic and ideological visions. Thus, the Algerian school system should articulate a capacity for interaction and exchange with the values of modernity, universality, globalization, democracy, and the ability to create and manage stabilizing social consensus.

One should not consider that any of the components the Algerian identity, namely 'Algerianity', Arabization, Tamazight and Islam as a threat to citizenship education. On the contrary, the government and the society at large should draw inspiration 
from theoretical data, favourable to the development of constructive and responsible critical capacities, in order to create a balance between the theoretical values studied and those experienced in everyday life. This dimension of citizenship education goes beyond the school itself to challenge the whole Algerian society in order to achieve global citizenship.

We can argue that the efforts undertaken by the Algerian state in post-colonial crisis succeeded in offering a new educational perspective to make sense of the existing dilemmas of multiculturalism and national citizenship deficits. Nevertheless, more research must be carried out to explore the concept of GCE in relation to multiculturalism and address the three main topics which affect education in multicultural societies in a globalized world: solving the issue of diversity in relation to creating citizens, the issue of equality and social justice in democratic societies, and the tension between the global and local in a globalized world.

Lessons can be learned from each of the two post-conflict contexts in Algeria. GCE offers not only a unifying theoretical framework but also a set of policy recommendations aimed at achieving national unity which could be multicultural, multiethnic and diversified, and where all categories of society participate, including women. Progress in individual rights has already been made in Algeria and the Berber population is the living proof of it. However, all categories of Algerian society feel the need to be globally legitimate, and are determined to pursue their mission towards change.

Algeria is on course to achieve political modernization and although the path is not smooth, the country is forging ahead towards a better future. Algerian youth have already passed the test; the protests of 22 February 2019 are a lesson to be learned by societies that hope to witness democracy. After several weeks of street protests, the president Bouteflika stepped down and many prominent figures of the regime were arrested on corruption charges. However, street demonstrations have continued and political negotiations are ongoing in August 2019. It is therefore obvious that full Citizenship for each Algerian is a prerequisite for a better tomorrow.

\section{References}

Abdellatif, N. (2014). Approche nationale de la diversité religieuse en Algérie : situation scolaire dans le secondaire. In Conseil de l'Europe (Ed.), Education et Diversité Religieuse en Méditerranée Occidentale (pp. 43-77). Strasbourg: Conseil de l'Europe.

Abdellatif, N. (2016). Dialogue des religions : situation scolaire en Algérie. Alger: Editions Djitli. Avanzini, G. (1998). Quelles finalités pour l'éducation? In J.-C. Ruano-Borbalan (Ed.), Eduquer et Former (pp. 47-49). Auxerre: Edition Sciences-Humaines.

Bendif, A. (2016). L'école algérienne et la problématique de l'éducation à la citoyenneté. Revue Sciences Humaines, 44, 127-145.

Brysk, A. (2009). Beyond framing and shaming: Human trafficking, human security and human rights. Journal of Human Security, 5(3), 8.

Déjeux, J. (2008). Situation de l'Arabisation en Algérie. Géopolitique Africaine, 7, 99-109.

Grandguillaume, G. (1997). Arabisation et Démagogie en Algérie. Le monde diplomatique, 515(3).

Jaramillo, R., \& José, A. M. (2009). Citizenship education as a response to Colombia's social and political context. Journal of Moral Education, 38(4), 467-487. 
Perrenoud, P. (1997). Apprentissage de la citoyenneté... des bonnes intentions au curriculum caché. In J.-C. Gracia (Ed.), Education, citoyenneté, territoire, Actes du séminaire national de l'enseignement agricole (pp. 32-54). Toulouse: ENFA.

Robertson, S. L. (2011). The new spatial politics of (re)bordering and (re)ordering. International Review of Education, 3-4(57), 277-297.

Rocher, G. (1970). L'organisation sociale. Paris: Editions HMH.

Salhi, Z. S. (2003). Algerian women, citizenship, and the 'family code'. Gender and Development, 11(3), 27-35.

Sarr, S. (2010). L'éducation à la citoyenneté : le rôle de l'école. In F. Jutras (Ed.), Enjeux socioéducatifs et pédagogiques (pp. 165-191). Québec: Presses de l'université du Québec.

Selye, H. (1956). The stress of life. New York: McGraw-Hill.

Toualbi-Thaalibi, N. (2005). Changement social, représentation identitaire er refonte de l'éducation en Algérie. In N. Toualbi-Thaalibi \& S. Tawil (Eds.), Le Refonte de la pédagogie en Algérie (pp. 19-32). Rabat: Bureau de l'UNESCO pour le Maghreb.

UNESCO. (1998). Citizenship education for the 21st century. Retrieved from http://www.unesco. org/education/tlsf/mods/theme_b/interact/mod07task03/appendix.htm

UNESCO. (2010). Teaching and learning for a sustainable future. Retrieved from http://www. unesco.org/education/tlsf/mods/theme_b/mod07.html

Zoubir, H. (2011). French-Algerian relations: The weight of history. Doha: AL Jazeera Centre for Studies.

Open Access This chapter is distributed under the terms of the Creative Commons Attribution 4.0 International License (http://creativecommons.org/licenses/by/4.0/), which permits use, duplication, adaptation, distribution and reproduction in any medium or format, as long as you give appropriate credit to the original author(s) and the source, a link is provided to the Creative Commons licence and any changes made are indicated.

The images or other third party material in this chapter are included in the work's Creative Commons licence, unless otherwise indicated in the credit line; If such material is not included in the work's Creative Commons licence and the respective action is not permitted by, users will need to obtain permission from the license holder to duplicate, adapt or reproduce the material.

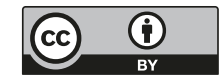

